\title{
Components of metabolic syndrome in relation to plasma levels of retinol binding protein 4 (RBP4) in a cohort of people aged 65 years and older
}

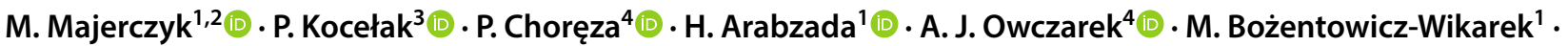 \\ A. Brzozowska ${ }^{3} \cdot$ A. Szybalska ${ }^{5}$ (1) M. Puzianowska-Kuźnicka ${ }^{6,7}$ (1) $\cdot$ T. Grodzicki $^{8}$ (1) A. Więcek ${ }^{9}$. \\ M. Olszanecka-Glinianowicz ${ }^{3}$ (1) $\cdot$ J. Chudek $^{10}$ (1)
}

Received: 28 November 2017 / Accepted: 26 February 2018 / Published online: 9 March 2018

(c) The Author(s) 2018. This article is an open access publication

\begin{abstract}
Purpose Elevated plasma concentration of retinol binding protein 4 (RBP4) has recently emerged as a potential risk factor as a component of developing metabolic syndrome (MS). Therefore, this study aimed to analyse the relationship between components of MS and concentrations of plasma RBP4 in a population of subjects 65 years and older.

Methods The study sample consisted of 3038 (1591 male) participants of the PolSenior study, aged 65 years and older. Serum lipid profile, concentrations of RBP4, glucose, insulin, C-reactive protein, IL-6, and activity of aminotransferases were measured. Nutritional status (BMI/waist circumference) and treatment with statins and fibrates were evaluated. Glomerular filtration rate (eGFR), de Ritis ratio, and fatty liver index (FLI), as well as HOMA-IR were calculated.

Results Our study revealed a strong relationship between components of MS and RBP4 in both sexes: plasma RBP4 levels were increased in men by at least $3 \times$, and in women by at least $4 \times$. Hypertriglyceridemia was most strongly associated with elevated plasma RBP4 levels. Multivariate, sex-adjusted regression analysis demonstrated that chronic kidney disease [OR 1.86 (95\% CI 1.78-1.94)], hypertriglyceridemia [OR 1.52 (1.24-1.87)], hypertension [OR 1.15 (1.12-1.19)], low serum HDL cholesterol [OR $0.94(0.92-0.97)$ ], and age $>80$ years [OR $0.86(0.81-0.90)$ ] were each independently associated with RBP4 concentration (all $p<0.001$ ).

Conclusions In Caucasians 65 years and older, RBP4 serum levels are associated with a number of components of MS, independent of sex and kidney function. Hypertriglyceridemia as a component of MS is most significantly related to RBP4 concentration.
\end{abstract}

Keywords RBP4 · Metabolic syndrome (MS) · MS components · Hypertension · Triglycerides $\cdot$ HDL

M. Majerczyk

majerczykmarcin@gmail.com

1 Pathophysiology Unit, Department of Pathophysiology, Medical Faculty in Katowice, Medical University of Silesia, Medyków Street 18, 40-752 Katowice, Poland

2 Department of Cardiology, District Hospital in Zakopane, Zakopane, Poland

3 Health Promotion and Obesity Management Unit, Department of Pathophysiology, Medical Faculty in Katowice, Medical University of Silesia, Katowice, Poland

4 Department of Statistics, School of Pharmacy with the Division of Laboratory Medicine in Sosnowiec, Medical University of Silesia, Katowice, Poland
5 International Institute of Molecular and Cell Biology, Warsaw, Poland

6 Department of Human Epigenetics, Mossakowski Medical Research Centre, PAS, Warsaw, Poland

7 Department of Geriatrics and Gerontology, Medical Centre of Postgraduate Education, Warsaw, Poland

8 Department of Internal Medicine and Gerontology, Jagiellonian University Medical College, Krakow, Poland

9 Department of Nephrology, Transplantation and Internal Medicine, Medical University of Silesia, Katowice, Poland

10 Department of Internal Medicine and Oncological Chemotherapy, Medical Faculty in Katowice, Medical University of Silesia, Katowice, Poland 


\section{Introduction}

Metabolic syndrome (MS) is a set of abnormalities which include visceral obesity, carbohydrate metabolism disturbances or type 2 diabetes, hypertriglyceridemia, decreased HDL cholesterol levels, and elevated blood pressure, [1-5]. Numerous studies have shown that the occurrence of components of MS significantly increases the risk of type 2 diabetes, cardiovascular diseases, and mortality in middle-aged populations [6-10].

Insulin resistance related to visceral obesity is the major pathway in the pathogenesis of MS [1-5]. Increased volume of visceral adipocytes is associated with local inflammation, followed by changes in adipokine release by visceral adipose tissue and low grade systemic inflammation. Both endocrine dysfunction of adipose tissue and systemic inflammation promote development of insulin resistance.

It has been shown that retinol binding protein 4 (RBP4) is one of the adipokines that participates in the development of insulin resistance by impairing insulin signalling at both the receptor and post-receptor levels, as well as by stimulation of liver gluconeogenesis [11]. The primary sources of RBP4 in vivo are hepatocytes and adipocytes [12]. Higher plasma RBP4 levels were reported in insulinresistant humans and mice $[11,13]$ as well as patients with type 2 diabetes [11, 14], hypertriglyceridemia [15], atherogenic dyslipidaemia [16, 17], and hypertension [18-20].

Plasma RBP4 level correlates with abdominal fat volume [21], waist circumference, BMI, and WHR [22, 23]. Stefan et al. [24] demonstrated that RBP4 level is mainly associated with the amount of fat in the liver and presumably with hepatic insulin resistance. In addition, a stronger correlation was observed between RBP4 levels and HOMA-IR values than that between RBP4 and waist circumference [14]. Finally, RBP4 level has been considered by some researchers to be a predictor of MS development in children $[25,26]$ and adults, and may be a new target for MS therapy [27].

The association between plasma RBP4 levels and BMI, HOMA-IR, or other components of MS in obese patients is questioned by some researchers [15], while other researchers demonstrate correlation with BMI only in crude comparison and not in models adjusted for age and sex (for example: the Third Generation Framingham Heart Study cohort [28]). In addition, some authors have shown a strong association between circulating RBP4 levels and the number of MS components [29, 30], while others indicated that age influences the association between RBP4 and MS components [31].

So far, no studies have assessed the relationship between RBP4 levels and components of MS in older adults. Hence, the aim of this study was to evaluate if there is a relationship between circulating RBP4 levels and components of MS in a large (65+), population-based Polish cohort.

\section{Methods}

\section{Study design and setting}

The PolSenior study, performed in the years 2007-2012, recruited six, similarly sized, age cohorts $(65-69,70-74$, $75-79,80-84,85-89,90$ years and older). During three visits performed by specially trained nurses, a questionnaire survey, comprehensive geriatric assessment, and measurements of body mass, height, waist circumference, and blood pressure were performed [32]. The current sub-study was based on data of 3038 available plasma samples stored at $-70{ }^{\circ} \mathrm{C}$ that were obtained from all project participants 65 years old and above in the morning after an overnight fast.

\section{Measurements}

Height and body mass were measured with the subjects wearing light clothes and no shoes (Tanita scale BC-536, Tokyo, Japan) with an accuracy of $0.5 \mathrm{~cm}$ and $0.1 \mathrm{~kg}$, respectively. The body mass index (BMI) was calculated according to the standard formula.

Waist circumference was measured midway between the last rib and the iliac crest in a standing position with the anterior axillary line guiding the tape-measure near the umbilicus with an accuracy of $0.5 \mathrm{~cm}$.

Blood pressure (BP) measurement was performed on the right upper arm, three times, in the sitting position after a 5-min rest using a fully automatic oscillometric BP measuring device accurate to $1 \mathrm{~mm} \mathrm{Hg}$ (A\&D Medical, Tokyo, Japan), with the cuff selected according to the arm circumference. Thirty min before BP readings, the subjects did not smoke cigarettes, drink coffee, or engage in physical exercise [33]. Mean value was calculated from two BP measurements.

\section{Laboratory parameters}

Plasma RBP4 concentrations were measured by ELISA (Immundiagnostik AG, Bensheim, Germany) with a 0.9-pg/ $\mathrm{mL}$ limit of sensitivity and with mean intra- and inter-assay coefficients of $<5.0$ and $<9.8 \%$, respectively. The standard range in adults reported by the manufacturer is $20-75 \mu \mathrm{g} /$ $\mathrm{mL}$.

Serum insulin concentration was assessed by electrochemiluminescence immunoassay (ECLIA) using commercially available kits on a Cobas E411 analyser (Roche 
Diagnostics GmbH, Mannheim, Germany) with an interassay coefficient of variability of $<3.8 \%$. Plasma interleukin-6 (IL-6) was measured by ELISA (R\&D Systems, Minneapolis, MN, USA) with a sensitivity of $0.04 \mathrm{pg} / \mathrm{mL}$ and mean intra-assay and inter-assay coefficient of variance $<7.8$ and $<7.2 \%$, respectively.

Serum total cholesterol, LDL cholesterol, HDL cholesterol, triglycerides, glucose, albumin, creatinine, and C-reactive protein concentrations, and activity of alanine (ALT), aspartate (AST) transaminases, and gamma-glutamyl transpeptidase (GGT) were previously assessed by an automated system (Modular PPE, Roche Diagnostics GmbH, Mannheim, Germany) in a single certified laboratory with inter-assay coefficients of variability below 1.7, 1.2, 1.3, 1.8, $1.7,1.7,2.3,5.7,4.4,3.2$, and $1.4 \%$, respectively.

\section{Data analysis}

Components of MS were diagnosed according to the IDF modified criteria [34]. Any three of the following components present in an individual warranted the diagnosis of MS: 1. visceral obesity for Europeans (waist circumference $\geq 94 \mathrm{~cm}$ in men and $\geq 80 \mathrm{~cm}$ in women), 2 . serum triglyceride level $\geq 1.7 \mathrm{mmol} / \mathrm{L}$ or treatment of hypertriglyceridemia, 3. low serum HDL-cholesterol concentration $<1.03 \mathrm{mmol} / \mathrm{L}$ in men and $<1.29 \mathrm{mmol} / \mathrm{L}$ in women or treatment of this condition, 4. systolic blood pressure $\geq 130 \mathrm{~mm} \mathrm{Hg}$ or/and diastolic blood pressure $\geq 85 \mathrm{~mm} \mathrm{Hg}$ or previously diagnosed hypertension, 5 . fasting plasma glucose $\geq 5.6 \mathrm{mmol} / \mathrm{L}$ or previously diagnosed type 2 diabetes.

Insulin resistance was assessed by HOMA-IR calculated with a standard formula. The de Ritis ratio (AST/ALT) was calculated and values greater than 1 were considered to be a surrogate marker of liver damage. Fatty Liver Index (FLI) was calculated according to the equation derived from the population of the Dionysos Nutrition \& Liver Study [35]; a score of 60 points or greater denoted hepatic steatosis. Glomerular filtration rate (eGFR) was estimated according to the MDRD formula [36].

\section{Statistical analysis}

Statistical analysis was performed using STATISTICA 10.0 PL (StatSoft, Tulsa, OK, US) and StataSE 12.0 (StataCorp LLC, College Station, TX, US). Statistical significance was set at a $p$ value below 0.05. All tests were two-tailed. Nominal and ordinal data were expressed as percentages, while interval data were expressed as the mean value \pm standard deviation in the case of a normal distribution or as median (lower quartile-upper quartile) in the case of data with skewed or non-normal distribution. Distribution of variables was evaluated by the Shapiro-Wilk test and quantile-quantile (QQ) plots. The
Levene test assessed homogeneity of variances. To evaluate the relationship between variables and RBP4 serum levels in three groups according to tertiles, the oneway ANOVA with Dunnett's post hoc test and two-way ANOVA (metabolic syndrome components and sex) with contrast analysis were used. The stepwise backwards multivariate ordinal logistic regression was used to assess factors influencing RPB4 serum levels. Comparison of data in ordinal and nominal scale was made either with the $\chi^{2}$ test or $\chi^{2}$ trend test.

\section{Results}

\section{RBP4 serum levels}

Similar plasma RBP4 levels were found in men and women (medians: 41.3 vs. $41.0 \mathrm{ng} / \mathrm{mL}, p=0.96$ ). Therefore, lower and upper tertiles were calculated jointly for men and women after logarithmic conversion because of heavy-skewed RBP4 distribution (below 33, between 33 and 51, and over $51 \mathrm{ng} / \mathrm{mL}$ ). Regardless of similar RBP4 values, but due to the differentiated distribution of components of MS between men and women, univariate analyses were done separately for men and women.

\section{Factors affecting plasma RBP4 concentration}

In the RBP4 tertile groups (Table 1), significant differences in the occurrence of hypertension and chronic kidney disease (CKD), serum triglyceride levels, GGT activity, FLI, and eGFR values were found in both men and women. Additionally, statistically relevant differences in diastolic blood pressure, type 2 diabetes occurrence, serum glucose level, and the de Ritis ratio $>1$ were noted between tertile groups only in women. Differences found only in men included the usage of fibrates (highest in the upper tertile) and serum levels of total and LDL cholesterol.

Multivariate stepwise ordered logistic regression analysis of factors influencing RBP4 levels revealed that chronic kidney disease had the strongest influence both in crude and sex-adjusted analyses. Other factors that positively correlated with RBP4 levels after sex adjustment were hypertriglyceridemia and a higher systolic BP. An inverse relationship was observed in the crude model for subjects in excess of 80 years of age and decreased serum HDL cholesterol concentration or its treatment. After sex adjustment, the de Ritis ratio $>1$ lost statistical relevance. Likelihood of fatty liver, expressed as FLI $>60$, did not correlate with RBP4 levels (Table 2). 
Table 1 Results of one-way ANOVA analysis separate for men and women in three groups according to RBP4 serum level tertiles

\begin{tabular}{|c|c|c|c|c|c|c|c|c|}
\hline \multirow[t]{2}{*}{ RBP4 tertile } & \multicolumn{4}{|l|}{ Women } & \multicolumn{4}{|l|}{ Men } \\
\hline & Lower $n=483$ & Middle $n=486$ & Upper $n=478$ & $P$ & Lower $n=530$ & Middle $n=527$ & Upper $n=534$ & $P$ \\
\hline Age, years & $78 \pm 9$ & $78 \pm 9$ & $77 \pm 8$ & 0.49 & $79 \pm 8$ & $79 \pm 9$ & $78 \pm 8$ & 0.12 \\
\hline $\begin{array}{l}\text { Age } \geq 80 \text { years, } \\
n(\%)\end{array}$ & $186(38.5)$ & $171(35.2)$ & $178(37.2)$ & 0.56 & $228(43.0)$ & $228(43.3)$ & $208(38.9)$ & 0.28 \\
\hline BMI $\left(\mathrm{kg} / \mathrm{m}^{2}\right)$ & $28.7 \pm 5.7$ & $28.9 \pm 5.2$ & $29.5 \pm 5.5$ & 0.10 & $27.3 \pm 4.4$ & $27.1 \pm 4.2$ & $27.6 \pm 4.8$ & 0.31 \\
\hline Obesity, $n(\%)$ & $186(38.5)$ & 193 (39.7) & $202(42.3)$ & 0.48 & $130(24.5)$ & $126(23.9)$ & $143(26.8)$ & 0.52 \\
\hline $\begin{array}{l}\text { Waist circumfer- } \\
\text { ence }(\mathrm{cm})\end{array}$ & $96.2 \pm 13.5$ & $96.1 \pm 13.3$ & $97.1 \pm 13.4$ & 0.45 & $100.0 \pm 12.7$ & $100.2 \pm 12.9$ & $101.4 \pm 12.5$ & 0.17 \\
\hline $\begin{array}{l}\text { Systolic BP } \\
(\mathrm{mmHg})\end{array}$ & $144.6 \pm 21.4$ & $147.5 \pm 21.2$ & $145.6 \pm 22.0$ & 0.10 & $143.2 \pm 20.1$ & $144.5 \pm 23.0$ & $146.3 \pm 22.5$ & 0.07 \\
\hline $\begin{array}{l}\text { Diastolic BP } \\
\text { (mmHg) }\end{array}$ & $84.2 \pm 10.6$ & $86.2 \pm 10.8^{*}$ & $85.0 \pm 11.1$ & $<0.05$ & $80.6 \pm 11.0$ & $81.5 \pm 11.6$ & $81.6 \pm 11.6$ & 0.28 \\
\hline $\begin{array}{l}\text { Hypertension, } \\
n(\%)\end{array}$ & $360(74.5)$ & $379(78.0)$ & $390(81.6)^{* *}$ & $<0.01^{\$}$ & $344(64.9)$ & $364(69.1)$ & $391(73.2)^{* *}$ & $<0.01^{\$}$ \\
\hline $\begin{array}{l}\text { Type } 2 \text { diabetes, } \\
n(\%)\end{array}$ & $106(21.9)$ & $115(23.7)$ & $139(29.1)^{* *}$ & $<0.01^{\$}$ & $107(20.2)$ & 119 (22.6) & $111(20.8)$ & 0.61 \\
\hline $\begin{array}{l}\text { Serum glucose } \\
(\mathrm{mmol} / \mathrm{L})\end{array}$ & $\begin{array}{c}93.8(84.5- \\
105.7)\end{array}$ & $\begin{array}{l}95.1(86.3- \\
107.0)\end{array}$ & $\begin{array}{c}96.8(86.9- \\
110.0)^{*}\end{array}$ & $<0.05$ & $\begin{array}{l}94.7(86.5- \\
106.4)\end{array}$ & $\begin{array}{c}96.0(86.5- \\
109.3)\end{array}$ & $\begin{array}{l}96.1(87.3- \\
107.4)\end{array}$ & 0.39 \\
\hline Insulin, $\mu \mathrm{IU} / \mathrm{mL}$ & $12.0(8.4-17.8)$ & $11.7(8.1-17.4)$ & $13.0(8.6-18.9)$ & 0.08 & $9.8(6.6-15.1)$ & $10.7(6.9-15.8)$ & $10.8(7.3-16.1)$ & 0.09 \\
\hline HOMA-IR & $\begin{array}{l}2.82(1.83- \\
4.22)\end{array}$ & $\begin{array}{l}2.80(1.74- \\
4.51)\end{array}$ & $\begin{array}{l}3.10(1.90- \\
4.78)\end{array}$ & 0.61 & $\begin{array}{l}2.34(1.41- \\
3.79)\end{array}$ & $\begin{array}{l}2.50(1.53- \\
4.25)\end{array}$ & $\begin{array}{l}2.60(1.59- \\
4.10)\end{array}$ & 0.10 \\
\hline $\begin{array}{l}\text { HOMA-IR } \geq 2.5 \\
n(\%)\end{array}$ & $286(59.2)$ & $274(56.4)$ & $297(62.1)$ & 0.19 & $245(46.2)$ & $261(49.5)$ & $274(51.3)$ & 0.24 \\
\hline ALT, U/L & $\begin{array}{l}19.7(16.1- \\
23.4)\end{array}$ & $\begin{array}{l}19.7(16.6- \\
23.3)\end{array}$ & $\begin{array}{l}19.0(16.0- \\
23.0)\end{array}$ & 0.55 & $\begin{array}{l}19.5(16.1- \\
23.0)\end{array}$ & $\begin{array}{l}19.9(16.6- \\
24.0)\end{array}$ & $\begin{array}{l}20.2(17.2- \\
24.0)\end{array}$ & 0.15 \\
\hline AST, U/L & $9.7(7.2-13.1)$ & $10.0(7.6-13.4)$ & $9.9(7.4-13.1)$ & 0.55 & $10.2(7.8-13.8)$ & $10.9(8.0-14.8)$ & $10.8(8.0-14.5)$ & 0.15 \\
\hline GGT, U/L & $\begin{array}{l}16.6(11.2- \\
25.5)\end{array}$ & $\begin{array}{l}16.0(11.7- \\
25.0)\end{array}$ & $\begin{array}{l}18.0 *(12.7- \\
26.6)\end{array}$ & $<0.05$ & $\begin{array}{l}18.6(13.3- \\
29.0)\end{array}$ & $\begin{array}{l}21.0(14.5- \\
31.1)\end{array}$ & $\begin{array}{l}22.4^{\#}(15.8- \\
35.0)\end{array}$ & $<0.001$ \\
\hline de Ritis ratio & $\begin{array}{l}0.51(0.39- \\
0.66)\end{array}$ & $\begin{array}{c}0.52(0.39 \\
-0.66)\end{array}$ & $\begin{array}{l}0.51(0.40- \\
0.67)\end{array}$ & 0.71 & $\begin{array}{l}0.54(0.41- \\
0.67)\end{array}$ & $\begin{array}{l}0.54(0.40- \\
0.71)\end{array}$ & $\begin{array}{l}0.54(0.41- \\
0.69)\end{array}$ & 0.79 \\
\hline $\begin{array}{l}\text { de Ritis }>1, n \\
\quad(\%)\end{array}$ & $14(2.9)$ & $19(3.9)$ & $31(6.5)^{* *}$ & $<0.05$ & $23(4.3)$ & $30(5.7)$ & $30(5.6)$ & 0.54 \\
\hline $\begin{array}{l}\text { Fatty liver index } \\
\text { (FLI) }\end{array}$ & $49.1 \pm 28.8$ & $50.4 \pm 29.1$ & $54.6 \pm 29.2 * *$ & $<0.01$ & $48.5 \pm 27.9$ & $49.9 \pm 27.2$ & $54.6 \pm 27.8^{\#}$ & $<0.001$ \\
\hline $\mathrm{FLI}>60, n(\%)$ & $185(38.3)$ & $201(41.4)$ & $223(46.7)^{* *}$ & $<0.05$ & $201(38.0)$ & $194(36.9)$ & $237(44.4)^{* *}$ & $<0.05$ \\
\hline $\begin{array}{l}\text { Total cholesterol, } \\
\mathrm{mmol} / \mathrm{L}\end{array}$ & $211.0 \pm 45.6$ & $213.9 \pm 46.7$ & $211.4 \pm 51.8$ & 0.59 & $187.4 \pm 39.8$ & $198.4 \pm 45.1^{\#}$ & $196.6 \pm 44.4^{* *}$ & $<0.001$ \\
\hline $\begin{array}{l}\text { LDL cholesterol, } \\
\mathrm{mmol} / \mathrm{L}\end{array}$ & $125.0 \pm 40.4$ & $126.5 \pm 39.6$ & $123.6 \pm 43.9$ & 0.54 & $111.9 \pm 35.7$ & $120.7 \pm 39.0^{\#}$ & $115.4 \pm 37.8$ & $<0.001$ \\
\hline $\begin{array}{l}\text { HDL cholesterol, } \\
\mathrm{mmol} / \mathrm{L}\end{array}$ & $53.0 \pm 13.8$ & $53.9 \pm 14.1$ & $53.3 \pm 14.8$ & 0.58 & $48.2 \pm 12.6$ & $48.7 \pm 13.7$ & $48.3 \pm 13.5$ & 0.79 \\
\hline $\begin{array}{l}\text { Triglycerides, } \\
\text { mmol/L }\end{array}$ & $\begin{array}{l}115.6(89.2- \\
150.0)\end{array}$ & $\begin{array}{c}121.0(91.6- \\
161.3)\end{array}$ & $\begin{array}{l}129.3^{\#}(98.3- \\
167.5)\end{array}$ & $<0.001$ & $\begin{array}{l}98.5(75.1- \\
131.3)\end{array}$ & $\begin{array}{l}104.5^{*}(84.2- \\
135.1)\end{array}$ & $\begin{array}{l}113.6^{\#}(88.7- \\
153.9)\end{array}$ & $<0.001$ \\
\hline Statins, $n(\%)$ & $114(23.6)$ & $121(24.9)$ & $138(28.9)$ & 0.15 & $112(21.1)$ & $117(22.2)$ & $139(26.0)$ & 0.14 \\
\hline Fibrates, $n(\%)$ & $7(1.4)$ & $3(0.6)$ & $9(1.9)$ & 0.21 & $2(0.4)$ & $7(1.3)$ & $12(2.2)$ & $<0.05$ \\
\hline hs-CRP, mg/L & $2.3(1.1-5.0)$ & $2.4(1.2-4.5)$ & $2.5(1.3-4.6)$ & 0.76 & $2.3(1.0-5.2)$ & $2.0(0.9-4.9)$ & $2.3(1.0-5.0)$ & 0.43 \\
\hline $\begin{array}{l}\text { hs- } \\
\text { CRP } \geq 3 \mathrm{mg} / \mathrm{L}, \\
n(\%)\end{array}$ & $205(42.4)$ & $200(41.1)$ & $207(43.3)$ & 0.79 & $222(41.9)$ & 207 (39.3) & $214(40.1)$ & 0.67 \\
\hline $\begin{array}{l}\text { Interleukin 6,pg/ } \\
\mathrm{mL}\end{array}$ & $2.2(1.5-3.7)$ & $2.2(1.4-3.4)$ & $2.0(1.4-3.4)$ & 0.34 & $2.6(1.6-4.3)$ & $2.4(1.6-3.8)$ & $2.2(1.3-3.8)$ & 0,08 \\
\hline $\begin{array}{c}\mathrm{eGFR}_{\mathrm{MDRD}} \mathrm{mL} / \\
\mathrm{min} / 1.73 \mathrm{~m}^{2}\end{array}$ & $79.9 \pm 20.6$ & $75.5 \pm 19.6^{\#}$ & $77.3 \pm 22.8^{\#}$ & $<0.001$ & $82.7 \pm 20.0$ & $77.9 \pm 19.8^{\#}$ & $75.1 \pm 23.8^{\#}$ & $<0.001$ \\
\hline
\end{tabular}


Table 1 (continued)

\begin{tabular}{|c|c|c|c|c|c|c|c|c|}
\hline \multirow[t]{2}{*}{ RBP4 tertile } & \multicolumn{4}{|l|}{ Women } & \multicolumn{4}{|l|}{ Men } \\
\hline & Lower $n=483$ & Middle $n=486$ & Upper $n=478$ & $P$ & Lower $n=530$ & Middle $n=527$ & Upper $n=534$ & $P$ \\
\hline $\begin{array}{l}\mathrm{eGFR}<60 \mathrm{~mL} / \\
\mathrm{min} / 1.73 \mathrm{~m}^{2}, \\
n(\%)\end{array}$ & $121(25.0)$ & 139 (28.6) & $185(38.7)^{\#}$ & $<0.001$ & $101(19.1 \%)$ & $150(28.5 \%)^{* *}$ & $178(33.3 \%)^{\#}$ & $<0.001$ \\
\hline
\end{tabular}

Data presented as mean value \pm SD or median (lower-upper quartile)

Bold values indicate statistically significant results

$B M I$ body mass index, $h s$-CRP C-reactive protein, $e G F R$ estimated glomerular filtration rate, HOMA-IR homeostatic model assessment of insulin resistance, $A L T$ alanine transaminase, $A S T$ aspartate transaminase

${ }^{\$}$ For trend; in comparison to the lower quartile: ${ }^{*} p<0.05 ; * * p<0.01 ;{ }^{*} p<0.001$

Table 2 Results of multivariable stepwise ordered logistic regression analysis of factors influencing plasma RBP4 levels

\begin{tabular}{|c|c|c|c|c|}
\hline \multirow[t]{2}{*}{ Factor } & \multicolumn{2}{|l|}{ Crude } & \multicolumn{2}{|c|}{ Sex-adjusted } \\
\hline & OR & $\pm 95 \% \mathrm{CI}$ & OR & $\pm 95 \% \mathrm{CI}$ \\
\hline Female & - & - & \multicolumn{2}{|c|}{$\begin{array}{l}\text { Not considered in the } \\
\text { model }\end{array}$} \\
\hline Age $>80$ years & $0.862 *$ & $0.749-0.991$ & $0.856^{\#}$ & $0.813-0.901$ \\
\hline Visceral obesity & - & - & - & - \\
\hline Serum triglycerides levels $\geq 150 \mathrm{mg} / \mathrm{dL}$ or treatment of hypertriglyceridemia & $1.494^{\#}$ & $1.281-1.741$ & $1.520^{\#}$ & $1.236-1.869$ \\
\hline $\begin{array}{l}\text { Serum HDL-cholesterol concentration: }<40 \mathrm{mg} / \mathrm{dL} \text { in men and }<50 \mathrm{mg} / \mathrm{dL} \text { in women or } \\
\text { treatment this lipid disturbances }\end{array}$ & - & - & $0.944^{\#}$ & $0.920-0.967$ \\
\hline $\begin{array}{l}\text { Systolic blood pressure } \geq 130 \mathrm{mmHg} \text { or/and diastolic blood pressure } \geq 85 \mathrm{mmHg} \text { or previ- } \\
\text { ously diagnosed hypertension }\end{array}$ & - & - & $1.152^{\#}$ & $1.116-1.188$ \\
\hline $\begin{array}{l}\text { Fasting plasma glucose } \geq 100 \mathrm{mg} / \mathrm{dL} \text { ( } \geq 5.6 \mathrm{mmol} / \mathrm{L} \text { ) or previously diagnosed type } 2 \\
\text { diabetes mellitus }\end{array}$ & - & - & - & - \\
\hline hs-CRP $>3 \mathrm{mg} / \mathrm{L}$ & - & - & - & - \\
\hline de Ritis ratio $>1$ & $1.392^{*}$ & $1.021-1.898$ & - & - \\
\hline FLI: $>60$ & - & - & - & - \\
\hline $\mathrm{eGFR}<60 \mathrm{~mL} / \mathrm{min} / 1.73 \mathrm{~m}^{2}$ & $1.858^{\#}$ & $1.573-2.195$ & $1.861^{\#}$ & $1.781-1.944$ \\
\hline
\end{tabular}

${ }^{*} p<0.05 ; * * p<0.01 ;{ }^{*} p<0.001$

\section{RBP4 and MS components}

Our study revealed a strong relationship between components of MS and RBP4, both in women $(p<0.01)$ and men $(p<0.001)$. Hypertriglyceridemia $(p<0.001$ for both sexes), occurrence of type 2 diabetes or fasting plasma glucose over $100 \mathrm{mg} / \mathrm{dL}(p<0.01, p<0.05$ for women and men, respectively) were substantially related to RBP4 levels (Table 3).

\section{RBP4 and the number of components of MS}

Two-way ANOVA was run to examine how the number of components of MS and sex influence the RBP4 serum levels. There was no significant interaction between the number of components of MS and sex $(p=0.88)$. Simple main effects analysis showed a significant association of the number of components of MS $(p<0.001)$ with the level of RBP4, but there were no differences between men and women $(p=0.39)$ (Fig. 1).

In comparison to the group without MS (less than three components of MS), RBP4 serum levels were higher in groups with at least three components for men and with at least four components for women (Fig. 1).

\section{Discussion}

Our large, population-based, cohort study shows that increased RBP4 serum levels are strongly associated with the presence and the number of components of MS in an $65+$ Caucasian population. These findings correspond with previous studies performed in multi-ethnic and over 65-yearold populations [37-39]. The findings support the hypothesis that RBP4 plays a role in the pathogenesis of the metabolic complications found in obesity. 
Table 3 Comparison of MS factors presence according to RBP4 serum level tertiles, separate for men and women

\begin{tabular}{|c|c|c|c|c|c|c|c|c|}
\hline \multirow[t]{2}{*}{ RBP4 tertile } & \multicolumn{4}{|l|}{ Women } & \multicolumn{4}{|l|}{ Men } \\
\hline & Lower $n=483$ & Middle $n=486$ & Upper $n=478$ & $P$ & Lower $n=530$ & Middle $n=527$ & Upper $n=534$ & $P$ \\
\hline $\begin{array}{l}\text { Metabolic syndrome, } \\
n(\%)\end{array}$ & $313(64.8)$ & $332(68.3)$ & $356(74.5)$ & $<0.01^{\$}$ & $258(48.7)$ & $282(53.5)$ & $323(60.5)$ & $<0.001^{\$}$ \\
\hline Visceral obesity, $n(\%)$ & 437 (90.5) & 432 (88.9) & $431(90.2)$ & 0.687 & $372(70.2)$ & 384 (72.9) & $407(76.2)$ & $<0.05^{\$}$ \\
\hline $\begin{array}{l}\text { Serum triglycerides } \\
\text { levels } \geq 150 \mathrm{mg} / \\
\mathrm{dL} \text { or treatment of } \\
\text { hypertriglyceridemia, } \\
n(\%)\end{array}$ & $128(26.5)$ & $149(30.7)$ & $178(37.2)$ & $<\mathbf{0 . 0 0 1}^{\$}$ & $83(15.7)$ & $101(19.2)$ & $157(29.4)$ & $<0.001^{\$}$ \\
\hline $\begin{array}{l}\text { Serum HDL choles- } \\
\text { terol concentration: } \\
<40 \mathrm{mg} / \mathrm{dL} \text { in men } \\
\text { and }<50 \mathrm{mg} / \mathrm{dL} \text { in } \\
\text { women or treatment } \\
\text { this lipid distur- } \\
\text { bances, } n(\%)\end{array}$ & $273(56.5)$ & $268(55.1)$ & $287(60.0)$ & 0.286 & $220(41.5)$ & $229(43.4)$ & $244(45.7)$ & 0.387 \\
\hline $\begin{array}{l}\text { Systolic blood pres- } \\
\text { sure } \geq 130 \mathrm{mmHg} \text { or/ } \\
\text { and diastolic blood } \\
\text { pressure } \geq 85 \mathrm{mmHg} \\
\text { or previously diag- } \\
\text { nosed hypertension, } \\
n(\%)\end{array}$ & 419 (86.7) & $437(89.9)$ & $431(90.2)$ & 0.168 & $434(81.9)$ & $429(81.4)$ & $457(85.6)$ & 0.140 \\
\hline $\begin{array}{l}\text { Fasting plasma glu- } \\
\text { cose } \geq 100 \mathrm{mg} / \mathrm{dL} \\
(\geq 5.6 \mathrm{mmol} / \mathrm{L}) \text { or } \\
\text { previously diagnosed } \\
\text { type } 2 \text { diabetes, } n(\%)\end{array}$ & $194(40.2)$ & $215(44.2)$ & $232(48.5)$ & $<0.01^{\$}$ & $210(39.6)$ & $251(47.6)$ & $240(44.9)$ & $<0.05$ \\
\hline $\begin{array}{l}\text { No. of metabolic syn- } \\
\text { drome factors }\end{array}$ & $3.0 \pm 1.2$ & $3.1 \pm 1.2$ & $3.3 \pm 1.2^{* * *}$ & $<0.01$ & $2.5 \pm 1.2$ & $2.6 \pm 1.2$ & $2.8 \pm 1.3^{\#}$ & $<0.001$ \\
\hline
\end{tabular}

Bold values indicate statistically significant results

${ }^{\$}$ For trend; in comparison to the lower quartile: $* p<0.05$; ** $p<0.01 ;{ }^{\#} p<0.001$

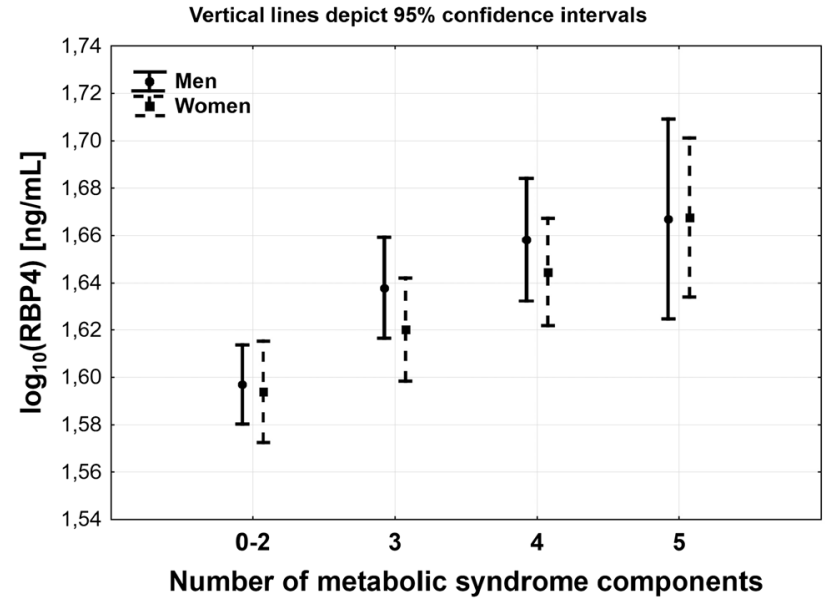

Fig. 1 RBP4 serum levels according to the number of metabolic syndrome factors, separated for men and women
In older adults the association between RBP4 levels and components of MS, especially carbohydrate disturbances, is weaker and affected by impaired renal function. The strong associations between RBP4, insulin resistance, and the percent of trunk fat in young subjects were shown to disappear in older adults [31]. However, an explanation of the phenomenon is missing.

A significant effect on RBP4 metabolism is impaired kidney function, which is frequently found in older adults. This supposition is supported by previously published data showing normalisation of RBP4 levels after kidney transplant [40-44] and by our results presenting an inverse relationship between eGFR and RBP4 levels. Unfortunately, the lack of assessment of kidney function in the numerous published studies may be a reason for the inconsistency of available data.

The most significant findings of our study are the associations between the levels of RBP4 and hypertriglyceridemia, as well as low HDL cholesterol levels (in the multivariate analysis). This suggests that RBP4 might play an 
important role in the disturbance of lipid synthesis in the liver, related to insulin resistance, and perhaps is a surrogate marker of liver steatosis. It was shown that RBP4 expression was aberrantly elevated in non-alcoholic fatty liver disease (NAFLD) in middle-age human and animal models, as well as positively associated with hepatic mitochondrial dysfunction combined with increased hepatic triglyceride accumulation [45, 46]. In vitro studies showed that RBP4 stimulated lipogenesis in HepG2 cells in a dose-dependent manner [47]. In line with these findings, we demonstrated a higher prevalence of subjects with increased FTI $>60$ and de Ritis index $>1$ in the highest RBP4 tertile. However, in multivariate regression analysis, both an increased FLI (strongly affected by triglyceride level) and the de Ritis index lost statistical significance. This suggests that RBP4 is one of many factors influencing hepatic lipogenesis and, therefore, its level is not a sensitive marker of NAFLD, at least in older adults.

A strong association between circulating levels of RBP4 and triglycerides seems to reflect the increased lipogenesis in the study subjects. This supposition is strengthened by Rocha et al., who demonstrated that on middle-aged, morbidly obese patients, RBP4 independently correlates with triglycerides, HDL, LDL, VLDL (very-low-density lipoprotein), and small-HDL subfractions of cholesterol; all particles enriched in triglycerides [17]. There are a couple of hypotheses explaining the stimulatory effect of RBP4 on lipogenesis. RBP4 has been shown to stimulate synthesis of SREBP-1 (sterol regulatory element-binding protein-1) and PPAR $\gamma$ (peroxisome proliferator-activated receptor gamma) in the liver, both proteins involved in lipogenesis [48]. RBP4 can also modulate lipid homeostasis indirectly, through retinoids, by activation of nuclear retinoid receptors. Finally, retinoids and retinol-binding proteins modulate apolipoprotein C-III production, an enzyme involved in the catabolism of VLDL (an inhibitor of lipoprotein lipase) and $\beta$-oxidation [49]. In a kinetic study, Verges et al. demonstrated reduced VLDL catabolism (VLDL-apolipoprotein B100 fractional catabolic rate) in diabetics with increased RBP4 levels [50].

This study has some limitations, such as the lack of validation of the utilised ELISA kit by a quantitative western blot analysis [23], liver sonography, and visceral fat depot assessment by DEXA or CT. It should be stressed that such measures are difficult to apply in population-based studies performed in their place of residence.

\section{Conclusions}

In older adult Caucasians, RBP4 serum levels are associated with a number of components of MS, independent of sex and kidney function. Hypertriglyceridemia as a component of MS is most significantly related to RBP4 concentration.

Acknowledgements Aleksandra Szybalska, Tomasz Grodzicki, Andrzej Więcek, Magdalena Olszanecka-Glinianowicz and Jerzy Chudek were researchers in the PolSenior study. This study was independently initiated and conducted by the authors as the PolSenior sub-study.

Funding The PolSenior study was a publicly funded project, No. PBZMEIN-9/2/2006, Ministry of Science and Higher Education. RBP4 assessments were covered by grants from the Medical University of Silesia (KNW-1-061/N/4/0).

\section{Compliance with ethical standards}

Conflict of interest On behalf of all authors, the corresponding author states that there is no conflict of interest. All authors have read and approved the final manuscript.

Ethical standards The study was approved by the Bioethics Committee of Medical University of Silesia (KNW/0022/KB1/38/II/08/10; KNW6501-38/I/08).

Informed consent All participants signed informed consent.

Open Access This article is distributed under the terms of the Creative Commons Attribution 4.0 International License (http://creativeco mmons.org/licenses/by/4.0/), which permits unrestricted use, distribution, and reproduction in any medium, provided you give appropriate credit to the original author(s) and the source, provide a link to the Creative Commons license, and indicate if changes were made.

\section{References}

1. Cornier MA, Dabelea D, Hernandez TL et al (2008) The metabolic syndrome. Endocr Rev 29:777-822. https://doi.org/10.1210/ er.2008-0024

2. Eckel RH, Grundy SM, Zimmet PZ (2005) The metabolic syndrome. Lancet 365:1415-1428. https://doi.org/10.1016/S0140 $-6736(05) 66378-7$

3. Haffner S, Cassells HB (2003) Metabolic syndrome-a new risk factor of coronary heart disease? Diabetes Obes Metab 5:359-370

4. Reaven GM (2005) The insulin resistance syndrome: definition and dietary approaches to treatment. Annu Rev Nutr 25:391-406. https://doi.org/10.1146/annurev.nutr.24.012003.132155

5. Reaven GM (1988) Role of insulin resistance in human disease. Diabetes 37:1595-1607

6. Alexander CM, Landsman PB, Teutsch SM et al (2003) NCEPdefined metabolic syndrome, diabetes, and prevalence of coronary heart disease among NHANES III participants age 50 years and older. Diabetes 52:1210-1214

7. Hanson RL, Imperatore G, Bennett PH et al (2002) Components of the 'metabolic syndrome' and incidence of type 2 diabetes. Diabetes 51:3120-3127 
8. Grundy SM (1999) Hypertriglyceridemia, insulin resistance, and the metabolic syndrome. Am J Cardiol 83:25F-29F

9. Lakka HM, Laaksonen DE, Lakka TA et al (2002) The metabolic syndrome and total and cardiovascular disease mortality in middle-aged men. JAMA 288:2709-2716

10. Schmidt C, Bergström GM (2012) The metabolic syndrome predicts cardiovascular events: results of a 13-year follow-up in initially healthy 58-year-old men. Metab Syndr Relat Disord 10:394-399. https://doi.org/10.1089/met.2012.0048

11. Yang Q, Graham TE, Mody N et al (2005) Serum retinol binding protein 4 contributes to insulin resistance in obesity and type 2 diabetes. Nature 436:356-362. https://doi.org/10.1038/nature0371 1

12. Esteve E, Ricart W, Fernández-Real JM (2009) Adipocytokines and insulin resistance: the possible role of lipocalin-2, retinol binding protein-4, and adiponectin. Diabetes Care 32(Suppl 2):S362-S367. https://doi.org/10.2337/dc09-S340

13. Graham TE, Yang Q, Blüher M et al (2006) Retinol-binding protein 4 and insulin resistance in lean, obese, and diabetic subjects. N Engl J Med 354:2552-2563. https://doi.org/10.1056/NEJMo a054862

14. Wang W, Li N (2015) Correlation of retinol binding protein 4 with metabolic indexes of glucose and lipid, bile cholesterol saturation index. J Cent South Univ 40:657-665. https://doi.org/10.11817/j.i ssn.1672-7347.2015.06.014

15. Ulgen F, Herder C, Kühn MC et al (2010) Association of serum levels of retinol-binding protein 4 with male sex but not with insulin resistance in obese patients. Arch Physiol Biochem 116:57-62. https://doi.org/10.3109/13813451003631421

16. Wu J, Hui Shi Y, Mei Niu D et al (2012) Association among retinol-binding protein 4, small dense LDL cholesterol and oxidized LDL levels in dyslipidemia subjects. Clin Biochem 45:619-622. https://doi.org/10.1016/j.clinbiochem.2012.02.022

17. Rocha M, Bañuls C, Bellod L et al (2013) Association of serum retinol binding protein 4 with atherogenic dyslipidemia in morbid obese patients. Moro C, editor. PLoS One 8:1-8. https://doi. org/10.1371/journal.pone.0078670

18. Solini A, Santini E, Madec S et al (2009) Retinol-binding protein-4 in women with untreated essential hypertension. Am J Hypertens 22:1001-1006. https://doi.org/10.1038/ajh.2009.116

19. Park CS, Ihm S-H, Park H-J et al (2011) Relationship between plasma adiponectin, retinol-binding protein 4 and uric acid in hypertensive patients with metabolic syndrome. Korean Circ J 41:198-202. https://doi.org/10.4070/kcj.2011.41.4.198

20. Majerczyk M, Choręza P, Bożentowicz-Wikarek M et al (2017) Increased plasma RBP4 concentration in older hypertensives is related to the decreased kidney function and the number of antihypertensive drugs-results from the Polsenior substudy. J Am Soc Hypertens 11(2):71-80. https://doi.org/10.1016/j. jash.2016.11.009

21. Gavi S, Qurashi S, Melendez MM et al (2007) Plasma retinolbinding protein- 4 concentrations are elevated in human subjects with impaired glucose tolerance and type 2 diabetes: response to Cho et al. Diabetes Care 30(3):e7. https://doi.org/10.2337/dc062276 (author reply e8)

22. Abualnaja S, Podder M, Hernandez AF et al (2015) Acute heart failure and atrial fibrillation: insights from the acute study of clinical effectiveness of nesiritide in decompensated heart failure (ASCEND-HF) trial. J Am Heart Assoc 4(8):e002092. https://doi. org/10.1161/JAHA.115.002092

23. Graham TE, Wason CJ, Blüher M et al (2007) Shortcomings in methodology complicate measurements of serum retinol binding protein (RBP4) in insulin-resistant human subjects. Diabetologia 50:814-823. https://doi.org/10.1007/s00125-006-0557-0

24. Stefan N, Hennige AM, Staiger H et al (2007) High circulating retinol-binding protein 4 is associated with elevated liver fat but not with total, subcutaneous, visceral, or intramyocellular fat in humans. Diabetes Care 30:1173-1178. https://doi.org/10.2337/ dc06-2342

25. Huang S-C, Yang Y-J (2013) Serum retinol-binding protein 4 is independently associated with pediatric NAFLD and fasting triglyceride level. J Pediatr Gastroenterol Nutr 56:145-150. https:// doi.org/10.1097/MPG.0b013e3182722aee

26. Boyraz M, Cekmez F, Karaoğlu A et al (2013) Relationship of adipokines (adiponectin, resistin and RBP4) with metabolic syndrome components in pubertal obese children. Biomark Med 7:423-428. https://doi.org/10.2217/bmm.13.14

27. Zhang X, Li M, Gao S et al (2012) Relationship between metabolic syndrome and adipokines on diabetes among high-risk populations. Zhonghua Liu Xing Bing Xue Za Zhi. 33:418-422

28. Kaess BM, Enserro DM, McManus DD et al (2012) Cardiometabolic correlates and heritability of fetuin-A, retinol-binding protein 4 , and fatty-acid binding protein 4 in the Framingham heart study. J Clin Endocrinol Metab 97:E1943-E1947. https:// doi.org/10.1210/jc.2012-1458

29. Lin CC, Lai MM, Li TC et al (2012) Relationship between serum retinol-binding protein 4 and visfatin and the metabolic syndrome. Diabetes Res Clin Pract 85:24-29. https://doi. org/10.1016/j.diabres.2009.03.016

30. Cho YM, Youn BS, Lee H et al (2006) Plasma retinol-binding protein- 4 concentrations are elevated in human subjects with impaired glucose tolerance and type 2 diabetes. Diabetes Care 29:2457-2461. https://doi.org/10.2337/dc06-0360

31. Gavi S, Qurashi S, Stuart LM et al (2008) Influence of age on the association of retinol-binding protein 4 with metabolic syndrome. Obesity 16:893-895. https://doi.org/10.1038/ oby. 2007.138

32. Bledowski P, Mossakowska M, Chudek J et al (2011) Medical, psychological and socioeconomic aspects of aging in Poland. Assumptions and objectives of the PolSenior project. Exp Gerontol 46:1003-1009. https://doi.org/10.1016/j.exger.2011.09.006

33. Zdrojewski T, Wizner B, Więcek A et al (2016) Prevalence, awareness, and control of hypertension in elderly and very elderly in Poland. J Hypertens 34:532-538. https://doi.org/10.1097/ HJH.0000000000000823

34. Alberti KGMM, Zimmet P, Shaw J (2006) Metabolic syndromea new world-wide definition. A consensus statement from the International Diabetes Federation. Diabet Med 23(5):469-480. https://doi.org/10.1111/j.1464-5491.2006.01858.x

35. Bedogni G, Bellentani S, Miglioli L et al (2006) The fatty liver index: a simple and accurate predictor of hepatic steatosis in the general population. BMC Gastroenterol 2(6):33. https://doi. org/10.1186/1471-230X-6-33

36. Levey AS, Bosch JP, Lewis JB et al (1999) A more accurate method to estimate glomerular filtration rate from serum creatinine: a new prediction equation. Ann Intern Med 130:461-470

37. Mostafaie N, Sebesta C, Zehetmayer S et al (2011) Circulating retinol-binding protein 4 and metabolic syndrome in the elderly. Wien Med Wochenschr 161:505-510. https://doi.org/10.1007/ s10354-011-0885-7

38. Liu Y, Wang D, Li D et al (2014) Associations of retinolbinding protein 4 with oxidative stress, inflammatory markers, and metabolic syndrome in a middle-aged and elderly Chinese population. Diabetol Metab Syndr 6:25. https://doi. org/10.1186/1758-5996-6-25

39. Lim S, Yoon JW, Choi SH et al (2010) Combined impact of adiponectin and retinol-binding protein 4 on metabolic syndrome in elderly people: the Korean longitudinal study on health and aging. Obesity 18:826-832. https://doi.org/10.1038/oby.2009.232

40. Chu CH, Lam HC, Lee JK et al (2011) Elevated serum retinolbinding protein 4 concentrations are associated with chronic 
kidney disease but not with the higher carotid intima-media thickness in type 2 diabetic subjects. Endocr J 58:841-847

41. Henze A, Frey SK, Raila J et al (2008) Evidence that kidney function but not type 2 diabetes determines retinol-binding protein 4 serum levels. Diabetes 57:3323-3326. https://doi.org/10.2337/ $\mathrm{db} 08-0866$

42. Akbay E, Muslu N, Nayir E et al (2010) Serum retinol binding protein 4 level is related with renal functions in type 2 diabetes. J Endocrinol Invest 33:725-729. https://doi.org/10.1007/BF033 46678

43. Barazzoni R, Zanetti M, Semolic A et al (2011) High plasma retinol binding protein 4 (RBP4) is associated with systemic inflammation independently of low RBP4 adipose expression and is normalized by transplantation in nonobese, nondiabetic patients with chronic kidney disease. Clin Endocrinol 75:56-63. https:// doi.org/10.1111/j.1365-2265.2011.03990.x

44. Zhang WX, Zhou W, Zhang ZM et al (2014) Decreased retinolbinding protein 4 in the sera of patients with end-stage renal disease after kidney transplantation. Genet Mol Res 13:8126-8134. https://doi.org/10.4238/2014.October.7.7

45. Liu $\mathrm{Y}, \mathrm{Mu} \mathrm{D}, \mathrm{Chen} \mathrm{H}$ et al (2016) Retinol binding protein 4 induces hepatic mitochondrial dysfunction and promotes hepatic steatosis. J Clin Endocrinol Metab 101(11):4338-4348. https:// doi.org/10.1210/jc.2016-1320
46. Zwolak A, Szuster-Ciesielska A, Daniluk J et al (2016) Chemerin, retinol binding protein-4, cytokeratin-18 and transgelin-2 presence in sera of patients with non-alcoholic liver fatty disease. Ann Hepatol 15:862-869. https://doi.org/10.5604/16652681.1222102

47. Xia M, Liu Y, Guo H et al (2013) Retinol binding protein 4 stimulates hepatic sterol regulatory element-binding protein 1 and increases lipogenesis through the peroxisome proliferatoractivated receptor- $\gamma$ coactivator $1 \beta$-dependent pathway. Hepatology 58:564-575. https://doi.org/10.1002/hep.26227

48. Muenzner M, Tuvia N, Deutschmann C et al (2013) Retinol-binding protein 4 and its membrane receptor STRA6 control adipogenesis by regulating cellular retinoid homeostasis and retinoic acid receptor $\alpha$ activity. Mol Cell Biol 33:4068-4082. https://doi. org/10.1128/MCB.00221-13

49. Staels B (2001) Regulation of lipid and lipoprotein metabolism by retinoids. J Am Acad Dermatol 45:S158-S167. https://doi. org/10.1067/mjd.2001.113718

50. Vergès B, Guiu B, Cercueil JP et al (2012) Retinol-binding protein 4 is an independent factor associated with triglycerides and a determinant of very low-density lipoprotein-apolipoprotein B100 catabolism in type 2 diabetes mellitus. Arterioscler Thromb Vasc Biol 32:3050-3057. https://doi.org/10.1161/ATVBA HA. 112.255190 